Article

\title{
Expected Impacts of the Massive Increase in Electric Vehicles in Slovakia
}

\author{
Jozef Živčák, Jaroslava Kádárová, Michal Puškár *, Michaela Kočišová and Laura Lachvajderová \\ Faculty of Mechanical Engineering, Technical University of Košice, Letná 9, 04200 Košice, Slovakia; \\ jozef.zivcak@tuke.sk (J.Ž.); jaroslava.kadarova@tuke.sk (J.K.); michaela.kocisova@tuke.sk (M.K.); \\ laura.lachvajderova@tuke.sk (L.L.) \\ * Correspondence: michal.puskar@tuke.sk
}

Received: 24 November 2020; Accepted: 10 December 2020; Published: 15 December 2020

\begin{abstract}
Society and the government perceive alternative propulsions as a way out of a world of high emissions. For several years now, European countries have been trying to enforce various strategic plans in which they give maximum support to electromobility. Subsidies and emission limits for car manufacturers or strategic plans for the development of electromobility in each European country are only a small part of the enormous support for the development of this new alternative drive. However, questions arise in the energy and ecology sectors: Is Slovakia ready to increase the number of electric vehicles? Will Slovakia have enough energy sources? Are electric cars really as clean as they are presented? The article focuses on these issues and, through detailed analysis, based on individual annual reports of each sector, refutes or confirms the fact that electromobility is a promising alternative and a replacement for internal combustion engines.
\end{abstract}

Keywords: electric vehicles; emissions; energy sources; analysis

\section{Introduction}

The Ministry of Economy of the Slovak Republic perceives an ever-increasing trend and consumer preferences tending to gradually shift from the use and consumption of traditional fossil fuels to alternative and sustainable energy sources. This trend is also becoming more pronounced in the field of transport, so it is essential that the planning of national as well as transnational initiatives, research and investment considers current and future needs in this area. One of the most significant trends and directions in the field of transport and mobility in Europe, and also in the Slovak Republic, is the ever-growing interest in the trend of electromobility.

The year 2020 is one of the milestones in the field of electromobility. EU regulators are still tightening emission limits, and it is this year that the target of limiting maximum $\mathrm{CO}_{2}$ emissions was set to $95 \mathrm{~g} / \mathrm{km}$. Of course, there are already several hybrids or plug-in hybrids today that meet this limit, but vehicles with internal combustion engines are far from fitting. The limit is calculated as an average for all vehicles sold by the car company during the year. According to this regulation, for every gram of $\mathrm{CO}_{2}$ produced above $95 \mathrm{~g} / \mathrm{km}$, the car company will pay a fine of 95 EUR. Thus, if a car company sells, for example, 100,000 vehicles on the European market, its fine will be EUR $95 \times 1 \mathrm{~g}$ $\mathrm{CO}_{2} \times 100,000$ vehicles $=$ EUR 9,500,000, in case the limit is exceeded by $1 \mathrm{~g}$. In order to meet these limits, in addition to gradually improving vehicles with internal combustion engines, the car company can help itself with zero-emission vehicles. Currently, the most popular advanced engines are vehicles with electric propulsion and vehicles with hydrogen fuel cells. Regulations and imminent fines are, of course, a sufficient incentive for car companies to focus on selling electrified vehicles. Sales of electric vehicles (EVs) and plug-in hybrid vehicles (PHEV) have seen a gradual increase in recent years and this trend can be expected to accelerate in the near future. Drivers' interest in EVs is increasing, and so 
this study focuses on analysis and comparison of electric drives with internal combustion engines in order to confirm or refute the claim that EVs is the way out of high emissions. The electric car is strictly evaluated in the energy and emissions sector. The calculations compare the self-sufficiency of the Slovak energy sector and, on the basis of annual reports and data from the previous year, it is determined whether or not the EV exceeds the European emission standards-EURO 6.

\section{Energy Balance in Slovakia}

In terms of electricity consumption, Slovakia is the smallest market compared to the surrounding countries. Since 2008, the Slovak Republic has been a net importer of electricity, but after the launch of new units 3 and 4 of the Mochovce Nuclear Power Plant, it will become an electricity exporter. The construction of new units represents the largest private investment in the history of Slovakia. The completion of units 3 and 4 of the nuclear power plant in Mochovce (MO34) is unique not only in Slovakia but also in the EU, where only four new nuclear units are currently being built-two of them in Mochovce. The output of each unit will be $471 \mathrm{MWe}$ and one reactor will cover $13 \%$ of electricity consumption in Slovakia [1]. The annual production of completed units will save more than 7 million tons of $\mathrm{CO}_{2}$ emissions, which will significantly contribute to the EU's plan to be carbon neutral by 2050 . The construction project is already finalized and the deadline for the initial introduction of nuclear fuel into the reactor is approaching.

The estimate of the development of electricity consumption assumes its approximately $1.2 \%$ year-on-year increase by 2030. In such a case, the consumption within the Slovak Republic will reach $35.2 \mathrm{TWh}$ in 2030 , while up to $87 \%$ of electricity will come from low-carbon sources [2]. Electricity has a specific position within energy sources (1). This position is due to the fact that the growth of its production and consumption may not be accompanied by a negative impact on the environment, as is the case with other types of fuels and energy. Electricity can be considered clean if it is produced and consumed with high efficiency, if it replaces the production of energy from the combustion of low-energy fuels or if it is produced from renewable energy sources (Figure 1).

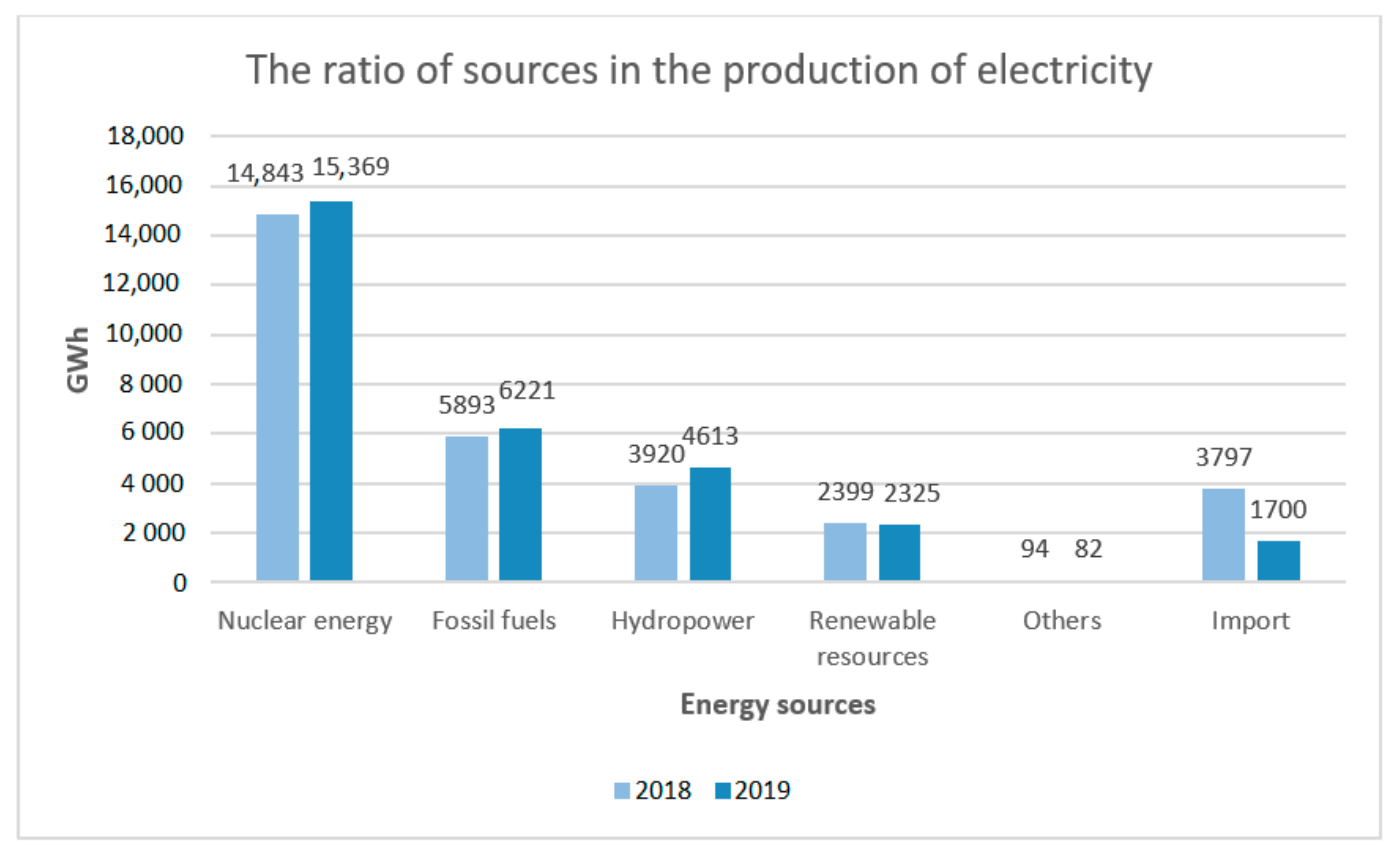

Figure 1. The ratio of energy sources in the production of electricity in Slovakia in 2018 and 2019 [3].

\section{Impact of the Increase in Electromobility on the Energy Industry}

In connection with the perspectives of the development of electromobility and the increase in the number of EVs (Figure 2), various opinions are also presented on whether or not electricity 
suppliers can manage the expected increase in the number of EVs and cover their consumption. Optimistic expectations in 2030 could be up to 50,000 EVs. The total electricity consumption in Slovakia is $32 \mathrm{TWh}$, so 50,000 passenger EVs would mean an increase in annual electricity consumption by $0.65 \%$. In such a percentage, it looks like an increment that power engineers can certainly handle. Predicting the number of EVs over a 10-year horizon is not an easy task. Various factors can enter into this issue. Therefore, in connection with the increase in electricity consumption, this study deals with an analysis, the task of which is to determine the approximate energy consumption of an EV and the impact of energy consumption in the development of electromobility on the electricity system $[4,5]$.

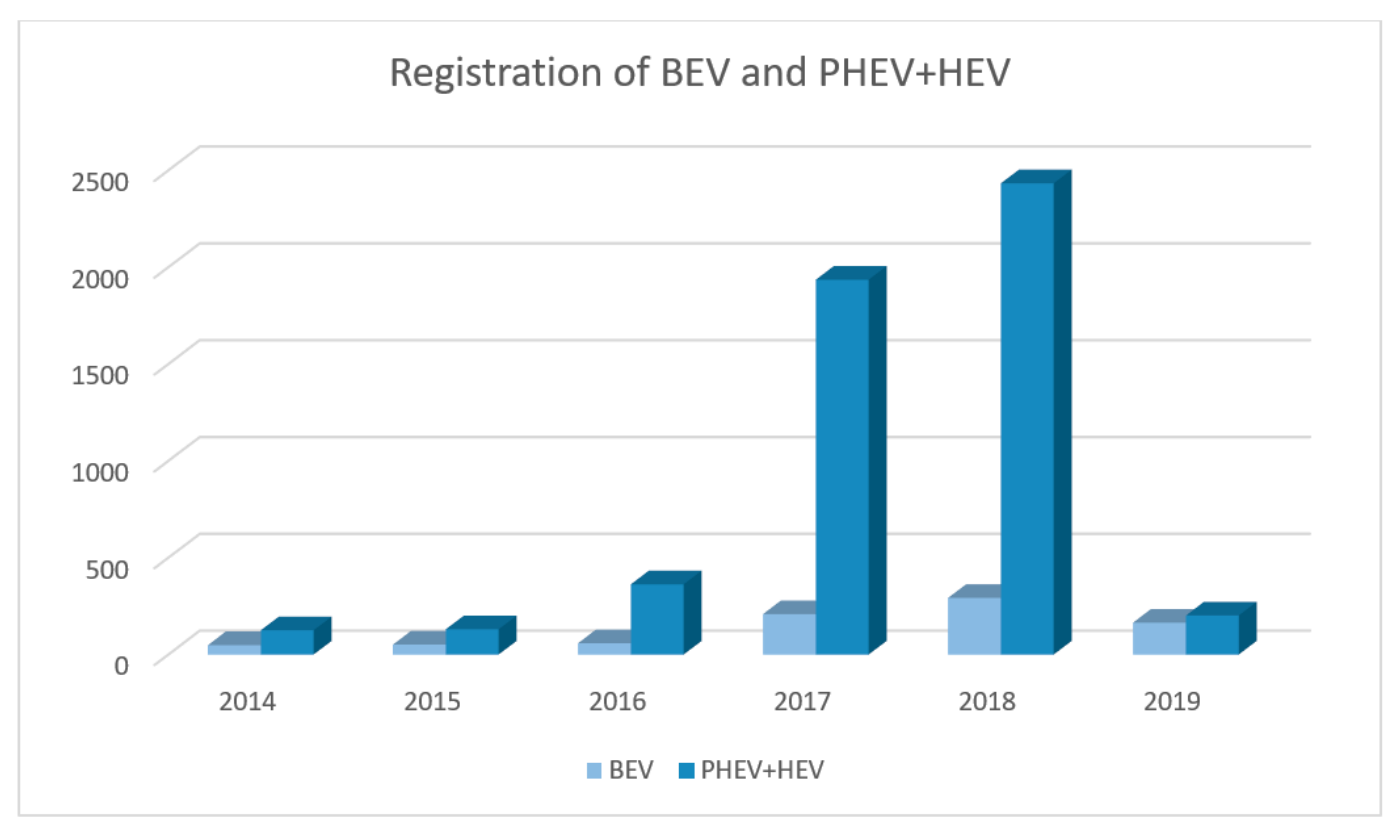

Figure 2. Registration of battery electric vehicle (BEV) and plug-in hybrid vehicles (PHEV) + hybrid electric vehicle (HEV) in 2014-2019 [6].

\subsection{Energy Consumption of an Electric Vehicle}

The average energy consumption of EVs is affected by a number of factors depending on the type of vehicle, the battery used or the type of recharging, which paradoxically results in the greatest energy losses. For recharging, an efficiency of about $80 \%$ is reported, which is based on the various measurements tested. According to [7], determination of the required energy for charging $1 \mathrm{kWh}$ is determined from the equation:

$$
P_{S}=P_{D} \cdot \frac{100}{\eta}=1 \cdot \frac{100}{80} \cong 1.25 \mathrm{kWh},
$$

where $\eta$ is the average charging efficiency $(\%), P_{S}$ is the energy taken from the electricity system $(\mathrm{kWh})$ and $P_{D}$ is the energy charged during the charging process to the electric vehicle battery $(\mathrm{kWh})$.

Therefore, it is obvious that in order to charge $1 \mathrm{kWh}$, it is necessary to produce $0.25 \mathrm{kWh}$. In the case that the energy losses in the power plants and losses in the transmission and distribution system were considered, this number would increase even more. Next, the calculated coefficient $k_{s}=1.25$ is considered. To determine the energy consumption when driving $100 \mathrm{~km}$, the data in Table 1 are used, which shows the average consumption of several models of EVs commonly found in the Slovak Republic. The average consumption of selected vehicles, according to the German Automobile Club (ADAC) based on Table 1, is 20,582 kWh per $100 \mathrm{~km}$. To this value, by adding the 
abovementioned coefficient, which indicates the electricity consumption for charging $1 \mathrm{kWh}$, the total electricity consumption per $100 \mathrm{~km}$ is achieved:

$$
P_{R E}=k_{S} \cdot P_{A D A C}=1.25 \cdot 20.582=25.73 \mathrm{kWh} / 100 \mathrm{~km},
$$

where $P_{R E}$ is the total energy required for $100 \mathrm{~km}$ of EV driving $(\mathrm{kWh} / 100 \mathrm{~km}), P_{A D A C}$ is the average energy consumption of an EV per $100 \mathrm{~km}$ according to ADAC $(\mathrm{kWh})$ and $k_{S}$ is a coefficient expressing the energy required to charge $1 \mathrm{kWh}$.

Table 1. Indicated versus real energy consumption (German Automobile Club (ADAC) [8]).

\begin{tabular}{ccc}
\hline Model & $\begin{array}{c}\text { Indicated Consumption by } \\
\text { Manufacturer } \mathbf{( k W h / 1 0 0 ~} \mathbf{k m})\end{array}$ & $\begin{array}{c}\text { Consumption Measured in } \\
\text { Ecotest } \mathbf{( k W h / 1 0 0 ~} \mathbf{k m})\end{array}$ \\
\hline Hyundai Ioniq Electric Style & 11.5 & 14.7 \\
VW e-Golf & 12.7 & 17.3 \\
BMW i3 94 Ah & 12.6 & 17.4 \\
Smart Fortwo Coupé EQ Prime & 12.9 & 18.3 \\
Opel Ampera-e First Edition & 14.5 & 19.7 \\
Renault Zoe Intens & 13.3 & 20.3 \\
Nissan Leaf Acenta (ZE0) & 15 & 20.5 \\
Nissan Leaf Acenta (ZE1) & 15.2 & 22.1 \\
Tesla Model S P90D & 20 & 24 \\
Tesla Model X 100D & 20.8 & 24 \\
Nissan e-NV200 Evalia & 25.9 & 28.1 \\
\hline
\end{tabular}

The calculation of energy consumption per $100 \mathrm{~km}$ makes it possible to calculate the annual consumption of an EV. Many sources state the annual rate for Slovak drivers is in the range 10-20,000 km [9]. Thus, it is an average of $12.500 \mathrm{~km}$ per year for a passenger car. With this value, another calculation will be entered, which consists of the equation:

$$
P_{\text {EVyear }}=\frac{P_{R E} \cdot 12500}{100}=\frac{25.73 \cdot 12500}{100} \cong 3216 \mathrm{kWh}=3216 \mathrm{MWh},
$$

where $P_{E V \text { year }}$ is the annual energy consumption of the EV (MWh).

These calculations are used to roughly estimate the energy consumption for EVs. At present, no official data on this issue are available, and therefore the values may be more or less different from reality and deviations should be considered. From the point of view of the analysis of the impact of electromobility on the electrical system, the average consumption according to the ADAC ecosystem is higher than the consumption stated by the manufacturer for all mentioned types of EVs.

\subsection{Influence of Energy Consumption in the Development of Electromobility on the Electricity System}

With the current low number of EVs in Slovakia, their impact on the electricity system is likely to be negligible. According to [6], the estimated number of BEVs in 2019 is considered to be 2000, and then the resulting annual energy consumption is:

$$
P_{E V 2019}=P_{E V \text { year }} \cdot 2000=3.216 \cdot 2000 \cong 6432 \mathrm{MWh} \cong 6432 \mathrm{GWh} \text {, }
$$

where $P_{E V 2019}$ is the energy consumed in 2020 at the considered number of BEVs (GWh).

According to the annual report of the Office for the Regulation of Network Industries (Figure 3), approximately 30,000 GWh of electricity was generated in 2019 [10]. In this case, the consumption of BEVs accounts for one-fifth of the total electricity produced, foreign import not included. Another question arises when it comes to the long-term development of electromobility. 


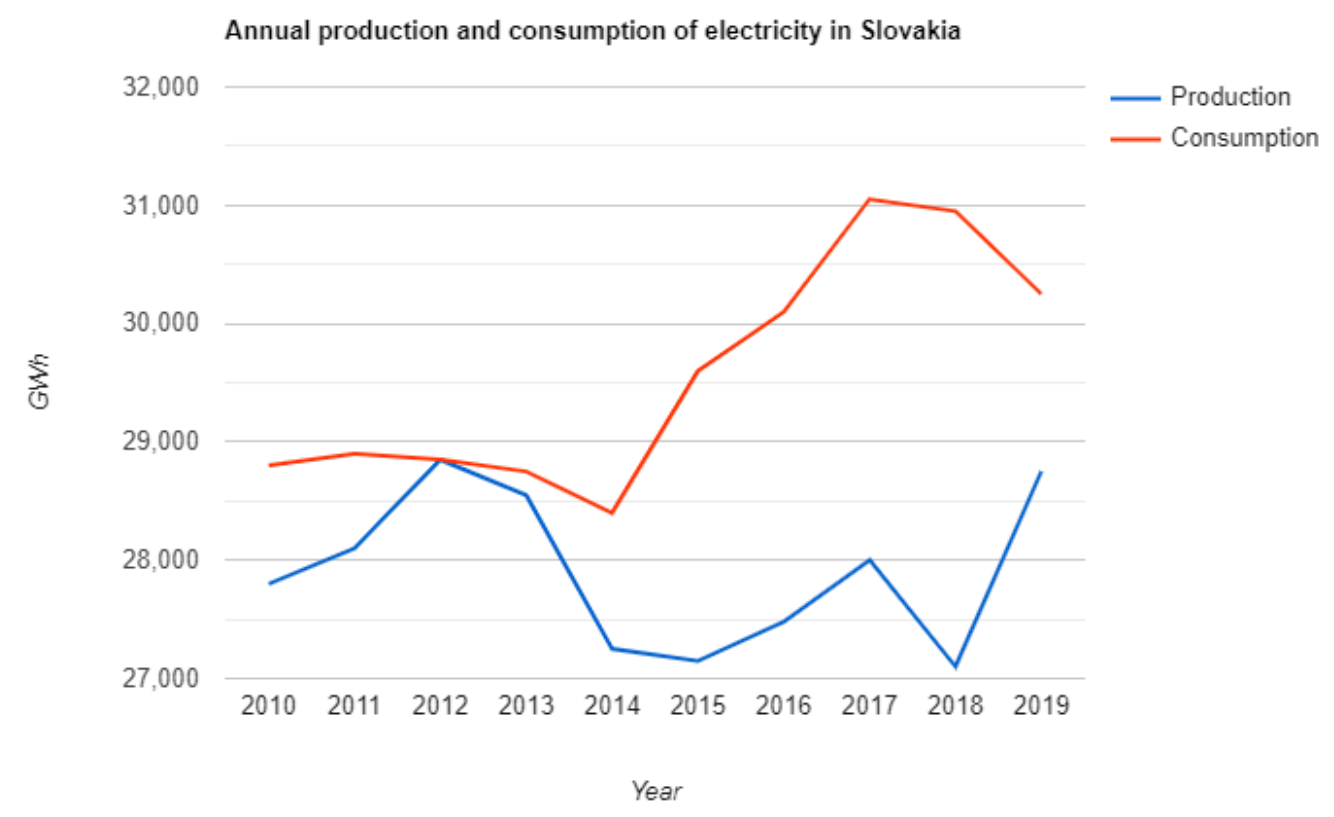

Figure 3. Annual production and consumption of electricity in Slovakia in the last 10 years [10].

At present, it is not possible to determine exactly in which direction this sector will develop in the future, but according to best knowledge, it can be assumed that alternative fuels will receive increasing attention. If it is based on the forecasts and goals of the Ministry of the Environment of the Slovak Republic, which focus on the number of 35,000 BEVs by 2030, an amount will be obtained that could already affect some sectors of the energy industry [11]. The annual energy consumption for operating this number of BEVs can be calculated using the following formula:

$$
P_{E V 2030}=P_{E V \text { year }} \cdot 35000=3.216 \cdot 35000 \cong 112560 \mathrm{MWh} \cong 112.6 \mathrm{GWh} .
$$

Due to the current annual production of electricity, it is already almost a $0.4 \%$ share. This increase in consumption will have to be addressed through various measures, such as the modernization and strengthening of the distribution system. The increase in electricity consumption in the field of transport is also shown in Figure 4 [12].

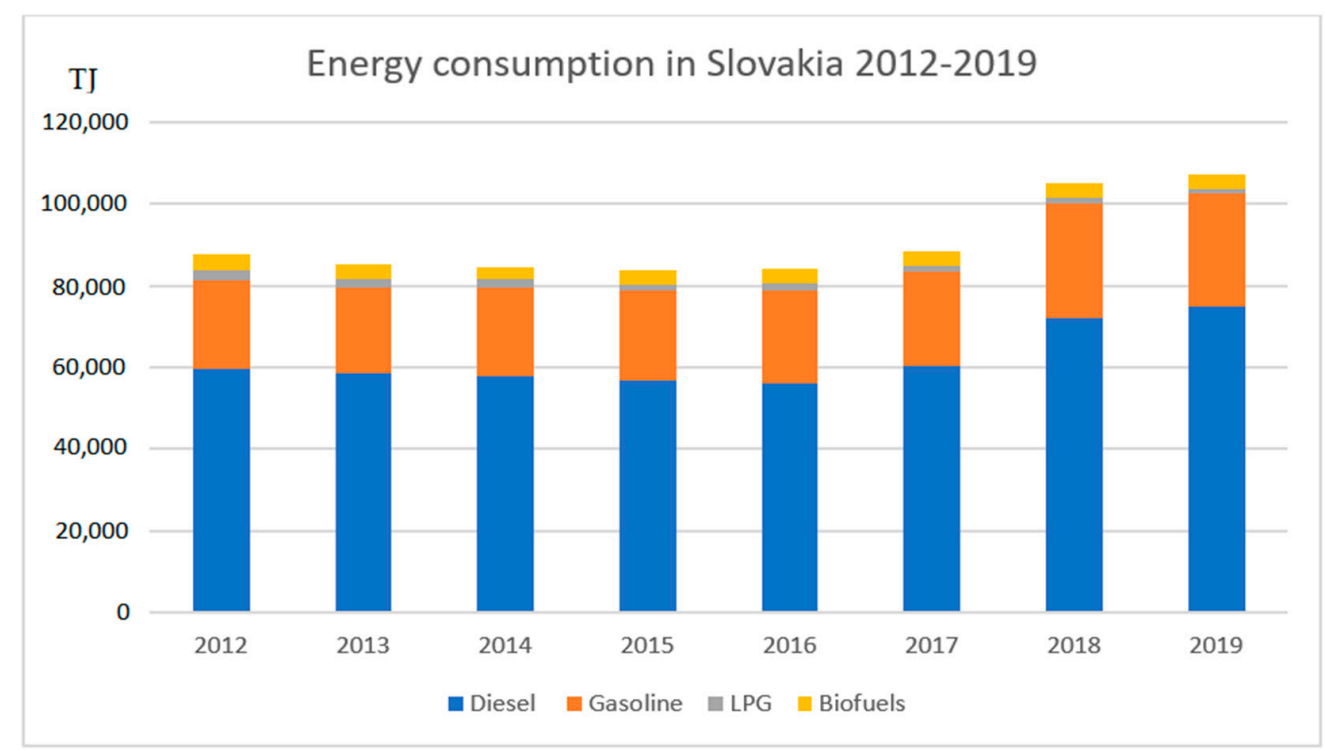

Figure 4. Energy consumption in road transport in the Slovak Republic, 2012-2019 [12]. 
The global trend of electromobility growth will most likely continue. Such an opinion appears in almost all forecasts about the future of electromobility, the energy sector or climate change. In its Global Outlook for Electric Vehicles scenarios, the IEA (International Energy Agency) predicts 130 million to 250 million EVs in 2030, with the share of EVs in the vehicle fleet, which should increase from $0.2 \%$ in 2016 to more than $5 \%$ in 2030 [13]. This forecast includes not only passenger and light commercial vehicles but also buses and lorries. It is obvious from these data that electromobility will increasingly contribute to energy consumption, but not to the extent that it can be described as a problem for which the future distribution network will have to prepare thoroughly. The increase in performance associated with it will not be enough to require extensive network modifications. One of the possible changes related to the increase in electromobility is more of local nature and is related to charging points. For high-performance charging stations, the phase voltages in the network could drop. This undesirable phenomenon is likely to be addressed by upgrading and strengthening transformers connected to the distribution system.

\section{Impact of the Increase in Electromobility on Ecology}

Electric vehicles are referred to as vehicles that do not produce any harmful emissions during operation. This is a key factor why electromobility might be a solution to reduce air pollution and the share of unwanted emissions, especially carbon dioxide. The goal of increased representation of EVs in the transport system is the transition to low-emission and non-emission forms of transport, which is a trend strategically defined at the level of the European Commission and is part of a low-carbon economy. Transport is currently responsible for a quarter of greenhouse gas emissions and is the dominant polluter, especially in urban areas. Road transport alone, in which electromobility is to be promoted the most, is responsible for $70 \%$ of greenhouse gas emissions in the transport sector. The goal of increased representation of EVs in the transport system is the transition to low-emission and non-emission forms of transport, which is a trend strategically defined at the level of the European Commission and is part of a low-carbon economy. Transport is currently responsible for a quarter of greenhouse gas emissions and is the dominant polluter, especially in urban areas. Road transport alone, in which electromobility is to be promoted the most, is responsible for $70 \%$ of greenhouse gas emissions in the transport sector. Emissions from car internal combustion engines also contribute to high concentrations of solid pollutants, which have a major impact on public health and the environment, and are a risk factor for the development of cardiovascular and respiratory diseases especially. The smallest fractions of solid particles especially are demonstrably the cause of many premature deaths in Europe and Slovakia. In Slovakia, transport accounts for more than $40 \%$ of total nitrogen oxide $\left(\mathrm{NO}_{\mathrm{x}}\right)$ emissions. The operation itself can be described as ecological, but the actual production of the EV and its components and the way in which electricity is produced is not. It is the energy mix that primarily determines how electromobility will more or less help to improve the overall ecological and emission situation.

\subsection{The $\mathrm{CO}_{2}$ Emissions}

Transport is responsible for $30 \%$ of all carbon dioxide emissions in the EU, with road transport accounting up to $72 \%$. The $\mathrm{EU}$ has therefore set the target of reducing $\mathrm{CO}_{2}$ emissions from transport by $60 \%$ by 2050 (compared to 1990 levels). This is a very ambitious plan, especially given that, while $\mathrm{CO}_{2}$ production is falling in other sectors, emissions in transport are rising with increasing mobility. The trend of developing higher fuel efficiency of new cars has also stopped. After a permanent decrease in the emissions produced by newly manufactured cars, new cars were measured for higher $\mathrm{CO}_{2}$ emissions in 2017-on average $0.4 \mathrm{~g}$ per kilometer more compared to vehicles manufactured in 2016. The European Union is therefore introducing new targets for reducing carbon dioxide emissions. Emission limits should fall by $37.5 \%$ for new passenger cars and by $31 \%$ for vans by 2030. On 18 April, 2019 members of the European Parliament (MEPs) also approved a proposal to reduce $\mathrm{CO}_{2}$ emissions from new trucks-by 2030 they should fall by 30\% compared to 2019 [14]. 
In terms of emissions of new vehicles, compared to other countries of the EU, Slovakia has nothing to boast about. In 2019, Slovakia occupied the second-worst place. Average $\mathrm{CO}_{2}$ emissions for new cars have risen to $133.4 \mathrm{~g} / \mathrm{km}$ this year, while the EU average is $121.8 \mathrm{~g} / \mathrm{km}$ [14]. At first glance, this is a small difference, but it is abysmal because the rest of the $\mathrm{EU}$ is fleeing to lower emissions. The lower share of diesel vehicles in Slovakia was also contributed to higher emissions by $25 \%$ compared to $32 \%$ in the European Union. While in 2018 they still had a share of $30.1 \%$ in registrations, last year their share decreased to $25.1 \%$. Petrol, which has lower emissions of nitrogen oxides $\left(\mathrm{NO}_{\mathrm{x}}\right)$ but produces more $\mathrm{CO}_{2}$ due to lower efficiency, was more successful. Their share increased from $66.49 \%$ to $69.9 \%$. Of the alternative drives, only hybrids have succeeded with only $4.24 \%$. BEVs, even though they were a big topic last year due to state subsidies for their purchase, they occupied only $0.16 \%$ of the market. According to an EU regulation, a car manufacturer after 2021 must produce only $95 \mathrm{~g}$ of carbon dioxide emissions per kilometer, otherwise, the car manufacturers will be forced to pay a corresponding fine. By 2030, car manufacturers should be offering at least 35\% BEVs and PHEVs. Electromobility is therefore one way of reducing ever-increasing emissions. [14] In order to calculate an EV's impact on the environment, it is necessary to consider the energy mix that is characteristic of the country. Emissions from the manufacture and disposal of a vehicle are higher for an EV than for an internal combustion EV (ICEV) [15] (Figure 5).

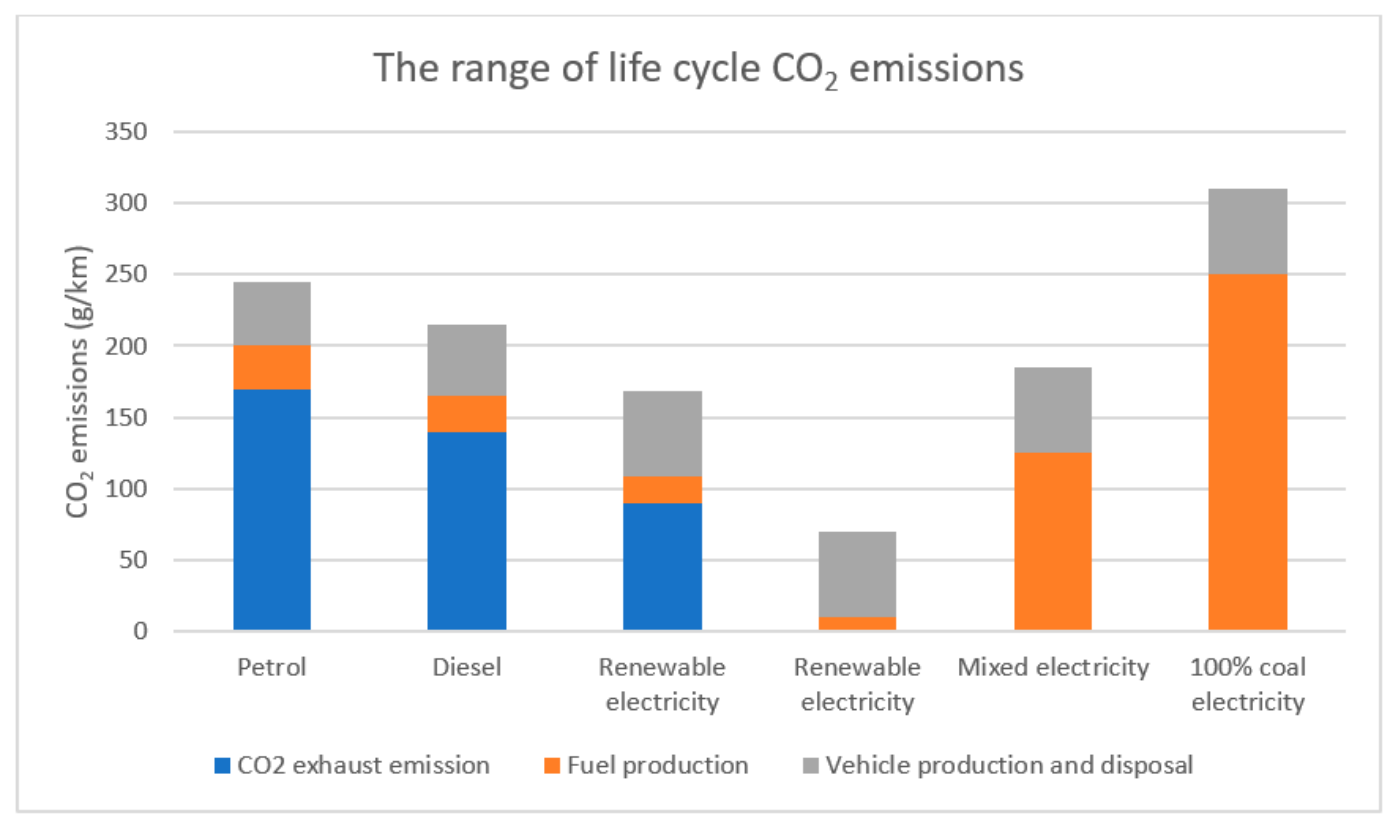

Figure 5. The range of life cycle $\mathrm{CO}_{2}$ emissions of different types of fuels [15].

If energy were produced only in coal-fired power plants, the emissions associated with fuel production would far outweigh internal combustion engines, in which case electromobility would be meaningless. In contrast, the energy obtained mainly from renewable sources is taken as the most ecological way that countries, not only in Europe, should apply. In particular, Asian countries such as India, China and Indonesia are facing this problem because much of their energy production comes from coal-fired power plants, which is why carbon dioxide emissions are highest in these countries. By contrast, France or Sweden, which use mainly nuclear sources, where electricity is mainly produced from renewable sources, has a satisfactory level of emissions from EVs. A more detailed description of the emission load for each country is shown in Table 2 [16]. 
Table 2. Average emissions of electric vehicles in selected countries [16].

\begin{tabular}{cc}
\hline Country & Total $\mathbf{C O}_{\mathbf{2}}$ Emissions $\left(\mathrm{g} \mathrm{CO}_{\mathbf{2}} \mathbf{e} / \mathbf{k m}\right)$ \\
\hline Iceland & 70 \\
Sweden & 81 \\
France & 93 \\
Germany & 179 \\
Great Britain & 189 \\
USA & 202 \\
China & 258 \\
Indonesia & 270 \\
Australia & 292 \\
South Africa & 318 \\
India & 370 \\
\hline
\end{tabular}

To calculate $\mathrm{CO}_{2}$ emissions in the Slovak Republic, it is first necessary to take into account the energy mix of the country (Table 3). More than half of the electricity supplied (55\%) comes from nuclear power, about a quarter $(26.9 \%)$ from fossil fuels and less than a fifth $(18 \%)$ from renewable energy sources (RES).

Table 3. Energy mix in Slovakia [4].

\begin{tabular}{cc}
\hline Energy Source & Ratio in Electricity Generation (\%) \\
\hline Other fossils & 0.57 \\
Other renewable & 1.44 \\
Oil & 1.49 \\
Wind power plants & 1.75 \\
Solar power plants & 1.82 \\
Biomass & 5.04 \\
Brown coal & 22.8 \\
Coal & 14.2 \\
Gas & 13.17 \\
Nuclear resources & 53.7 \\
Hydroelectric power plants & 8.08 \\
\hline
\end{tabular}

It is also necessary to indicate the emissions that will be produced by power plants using individual fuels (Table 4) related to the kWh produced. In the case of hydro, solar, wind and nuclear power plants, emissions from the production of these power plants are also included and are therefore not considered to be completely emission-free. For coal-fired power plants, calculations were performed to determine the exact values of carbon dioxide emissions.

Table 4. $\mathrm{CO}_{2}$ emissions depending on fuel and type of power plant [17].

\begin{tabular}{cc}
\hline Energy Source & $\mathbf{C O}_{\mathbf{2}}$ Emissions $(\mathbf{g} / \mathbf{k W h})$ \\
\hline Coal & 1180 \\
Brown coal & 958 \\
Oil & 920 \\
Gas & 790 \\
Nuclear & 82 \\
Solar & 37 \\
Wind & 28 \\
Hydropower & 23 \\
\hline
\end{tabular}

The $\mathrm{CO}_{2}$ emissions that result from the production of $1 \mathrm{kWh}$ by burning a corresponding amount of brown coal can be quantified by the following calculation, in which the amount of coal needed to 
produce $1 \mathrm{kWh}$ is first determined and then the carbon dioxide emission value is calculated for this amount. The first step in the calculation is to determine the output of brown coal power plants:

$$
P_{B C \text { year }}=e l_{\text {total } / 2019} \cdot r_{\% B C}=30000 \cdot 0.228 \cong 6840 \mathrm{GWh} / \text { year, }
$$

where $P_{B C \text { year }}$ is electricity produced by brown coal power plants (GWh/year), el $l_{\text {total } / 2019}$ is total electricity production in 2019 (GWh/year) and $r_{\% B C}$ is the ratio of brown coal in the energy mix of the Slovakia [10].

The conversion obtains:

$$
P_{B C}=\frac{P_{B C \text { year }} \cdot 1000}{\text { hours }_{\text {year }}}=\frac{6840 \cdot 1000}{365 \cdot 24} \cong 781 \mathrm{MW},
$$

where $P_{B C}$ is the average power of brown coal power plants (MW) and hours $s_{\text {year }}$ is number of hours per year.

It is also necessary to consider the heat value of brown coal, which is commonly used in Slovakia. At present, brown coal in Slovakia has an average heat value of $11 \mathrm{MJ} / \mathrm{kg}$. Furthermore, the thermal efficiency in the production of energy in coal-fired power plants is considered, which is around $38 \%$ [18].

$$
m_{\text {poh }}=\frac{P_{B C}}{\eta \cdot Q_{r}^{i}}=\frac{781000}{0.38 \cdot 11000} \cong 186.84 \frac{\mathrm{kg}}{\mathrm{s}}=672624 \mathrm{~kg} / \mathrm{h},
$$

where $m_{\text {poh }}$ is amount of brown coal consumed in coal-fired power plants per one hour $(\mathrm{kg} / \mathrm{h}), P_{B C}$ is the average power of brown coal power plants $(\mathrm{kW}), \eta$ is thermal efficiency of coal power plants and $Q_{r}^{i}$ is heat value of brown coal $(\mathrm{kJ})$.

In order to determine the amount of brown coal needed to produce $1 \mathrm{kWh}$, the following calculation is used:

$$
m_{1 k W h}=\frac{m_{p o h}}{P_{B C}}=\frac{672624}{781000} \cong 0.861 \mathrm{~kg} / \mathrm{kWh},
$$

where $m_{1 \mathrm{kWh}}$ is amount of brown coal to produce $1 \mathrm{kWh}(\mathrm{kg} / \mathrm{kWh})$.

From this value, the amount of $\mathrm{CO}_{2}$ produced by burning a specified number of brown coals is then determined. First, the proportion of carbon in this fuel is determined. The composition of coal is commonly stated as:

$$
C+H+S+O+N+W+A=100 \%,
$$

where $C, H, S, O, N$ corresponds to the percentage of flammable components of each element (\%), $W$ is water content (\%) and $A$ is ash content (\%).

Carbon is represented by about $26.4 \%$. Thus, one kilogram of brown coal corresponds to $0.264 \mathrm{~g}$ of carbon [19].

If ideal combustion is considered, the following equation is used:

$$
\mathrm{C}+\mathrm{O}_{2} \rightarrow \mathrm{CO}_{2}
$$

Based on the determined molar masses (see Table 5), the molar mass of carbon dioxide can be determined and then the amount of carbon dioxide produced by burning $1 \mathrm{~kg}$ of carbon can be determined.

$$
M_{\mathrm{CO}_{2}}=M_{\mathrm{C}}+M_{\mathrm{O}_{2}}=12.011+(2 \cdot 15.9994)=44.0098 \mathrm{~g} / \mathrm{mol},
$$

where $M_{\mathrm{CO}_{2}}$ is molar mass of carbon dioxide $(\mathrm{g} / \mathrm{mol}), M_{\mathrm{C}}$ and $M_{\mathrm{O}_{2}}$ is the molar mass of carbon and oxygen $(\mathrm{g} / \mathrm{mol})$, respectively, then:

$$
m_{\mathrm{CO}_{2} 1 \mathrm{kgC}}=\frac{M_{\mathrm{CO}_{2}}}{M_{\mathrm{C}}}=\frac{44.0098}{12.011}=3.664 \mathrm{~kg},
$$


where $m_{\mathrm{CO}_{2} 1 \mathrm{kgC}}$ is amount of carbon dioxide produced by burning $1 \mathrm{~kg}$ of carbon $(\mathrm{kg})$.

Table 5. The molar mass of selected elements [20].

\begin{tabular}{cc}
\hline Element & Molar Mass $(\mathrm{g} / \mathbf{m o l})$ \\
\hline Carbon & 12.011 \\
Hydrogen & 1.008 \\
Nitrogen & 14.007 \\
Oxygen & 15.9994 \\
Sulfur & 32.06 \\
\hline
\end{tabular}

This value multiplied by the carbon content of brown coal according to [18] determines the amount of $\mathrm{CO}_{2}$ produced by burning $1 \mathrm{~kg}$ of brown coal, as follows:

$$
m_{\mathrm{CO}_{2} B C}=m_{\mathrm{CO}_{2}} \cdot \% C_{B C}=3.664 \cdot \frac{26.4}{100} \cong 0.9673 \mathrm{~kg},
$$

where $m_{\mathrm{CO}_{2} B C}$ is amount of carbon dioxide produced by burning $1 \mathrm{~kg}$ of brown coal $(\mathrm{kg})$ and $\% C_{B C}$ is percentage of carbon in brown coal.

The resulting value of carbon dioxide produced by burning the amount of brown coal needed to produce $1 \mathrm{kWh}$ will be:

$$
m_{\mathrm{CO}_{2} B C 1 k W h}=m_{\mathrm{CO}_{2} B C} \cdot m_{1 k W h}=0.9673 \cdot 0.861 \cong 0.833 \mathrm{~kg} / \mathrm{kWh},
$$

where $m_{\mathrm{CO}_{2} B C 1 \mathrm{kWh}}$ is the value of carbon dioxide released during the production of $1 \mathrm{kWh}(\mathrm{kg} / \mathrm{kWh})$.

Such a structured calculation can also be performed to determine $\mathrm{CO}_{2}$ emissions from the combustion of black coal. It is necessary to recalculate all formulas with the corresponding coefficients, consider the ratio of black coal in the energy mix, its heat value and the percentage of carbon. An almost identical calculation with the changed values results in $1.306 \mathrm{~kg}$ of carbon dioxide, which is produced by burning the amount of black coal needed to produce $1 \mathrm{kWh}$. From these data it is possible to calculate carbon dioxide emissions corresponding to one kilowatt hour produced based on the following formula:

$$
\begin{gathered}
m_{\mathrm{CO}_{2}}=\left(m_{\mathrm{CO}_{2} B C} \cdot p_{B C}\right)+\left(m_{\mathrm{CO}_{2} \text { coal }} \cdot p_{\text {coal }}\right)+\left(m_{\mathrm{CO}_{2} \text { oil }} \cdot p_{\text {oil }}\right)+\left(m_{\mathrm{CO}_{2 g a s}} \cdot p_{\text {gas }}\right)+ \\
\left(m_{\mathrm{CO}_{2} \text { solar }} \cdot p_{\text {solar }}\right)+\left(m_{\mathrm{CO}_{2} \text { nuclear }} \cdot p_{\text {nuclear }}\right)+\left(m_{\mathrm{CO}_{2} \text { hydro }} \cdot p_{\text {hydro }}\right)+\left(m_{\mathrm{CO}_{2} \text { wind }} \cdot p_{\text {wind }}\right)= \\
\left(958 \cdot \frac{22.8}{100}\right)+\left(1180 \cdot \frac{14.2}{100}\right)+\left(920 \cdot \frac{1.49}{100}\right)+\left(790 \cdot \frac{13.17}{100}\right)+\left(37 \cdot \frac{1.82}{100}\right)+ \\
\left(82 \cdot \frac{53.7}{100}\right)+\left(23 \cdot \frac{8.08}{100}\right)+\left(28 \cdot \frac{1.75}{100}\right)=550.79 \mathrm{~g} / \mathrm{kWh},
\end{gathered}
$$

where $m_{\mathrm{CO}_{2}}$ represents the total mass of $\mathrm{CO}_{2}$ related to the production of $1 \mathrm{kWh}(\mathrm{g} / \mathrm{kWh}), m_{\mathrm{CO}_{2} n}$ represents the mass of $\mathrm{CO}_{2}$ according to the type of fuel $(\mathrm{n})$ per $1 \mathrm{kWh}(\mathrm{g} / \mathrm{kWh})$ and $p_{n}$ represents the percentage ratio of individual energy sources in the energy mix of Slovakia.

In order to be able to use this value, it must be converted to $\mathrm{CO}_{2}$ emissions per kilometer. First, it will be based on ADAC's measured consumption of EVs from Table 1, which is multiplied by a coefficient including charging losses. This value is $25.73 \mathrm{kWh} / 100 \mathrm{~km}$ and is further calculated as follows:

$$
m_{\mathrm{CO}_{2} / 1 \mathrm{~km}}=P_{R E} \cdot \frac{m_{\mathrm{CO}_{2}}}{100}=25.73 \cdot \frac{550.79}{100} \cong 141.72 \mathrm{~g} / \mathrm{km},
$$

where $m_{\mathrm{CO}_{2} / 1 \mathrm{~km}}$ is the amount of $\mathrm{CO}_{2}$ emissions driven per kilometer $(\mathrm{g} / \mathrm{km})$ and $P_{R E}$ is the average consumption of EVs based on Table $1(\mathrm{kWh} / 100 \mathrm{~km})$.

In the current energy situation, the value of carbon dioxide emissions per kilometer of EV is almost $50 \mathrm{~g}$ more than allowed by the prescribed standard for 2021. This value is mainly influenced by fossil fuels, which are now still abundant in the domestic energy sector. It is expected that their 
use will decrease in the future and low-emission energy sources, especially renewables and nuclear sources, will be preferred. In such an expected course, emissions from EVs would fall significantly and, from an ecological point of view, electromobility would help to eliminate these emissions. To illustrate, following example explains: if the ratio of fossil fuels in the energy mix of the Slovak Republic was halved and the ratio of renewable energy sources increased proportionally, the EV would reach a value of approximately $66 \mathrm{~g}$ of carbon dioxide per kilometer.

\subsection{The Rest of the Emissions}

Other significant emissions are nitrogen oxides, commonly referred to as $\mathrm{NO}_{\mathrm{x}}$, most commonly referred to as nitric oxide $\mathrm{NO}$ and nitrogen dioxide $\mathrm{NO}_{2}$. Due to these and other pollutants, EURO emission standards have been introduced in the European Union since 1992. These standards control and regulate the amount of not only nitrogen oxides, but also carbon monoxide (CO), hydrocarbons (HC) and particulate matter (PM) per kilometer driven. These standards are gradually being modernized, adjusted and new ones are being published at intervals of about five years. Newly issued standards are numbered depending on the type of vehicles for which they are intended. For passenger vehicles and light commercial vehicles, the standard is given in Arabic numerals and for buses and heavy trucks, the standards are indicated by Roman numerals. It is important to mention that the standard only applies to vehicles that are newly introduced on the market. The latest valid standard is EURO 6, which came into force in 2015 (see Table 6), which was later further tightened by version 6.2. A new emission measurement methodology has started to be applied, which is more demanding, more accurate and better suited to real driving style. It is a method of laboratory testing WLTP (worldwide harmonized light vehicle test procedure). In addition to laboratory testing, the RDE (real driving emissions) cycle is also used to measure emissions, so measurements are made directly on the road. The new standard applies to all manufactured vehicles, including older models. For car manufacturers, this means modifying selected engines [21-28].

Table 6. Overview of EURO 6 emission limits [22].

\begin{tabular}{cccc}
\hline & $\mathrm{CO}(\mathrm{g} / \mathbf{k m})$ & $\mathrm{NO}_{\mathbf{X}}(\mathrm{g} / \mathbf{k m})$ & $\mathrm{PM}(\mathrm{g} / \mathbf{k m})$ \\
\hline Gasoline & 1.00 & 0.06 & $0.005^{*}$ \\
Diesel & 0.50 & 0.08 & 0.005 \\
\hline \multicolumn{4}{c}{}
\end{tabular}

The emissions of the EV will be related to the value of emissions released into the air by the power plants in the production of the required electricity, similarly as it was for the determination of carbon dioxide emissions. In the calculation, it is necessary to know the emission factor of different types of power plants producing harmful emissions in relation to the amount of electricity produced, which is shown in Table 7.

$$
\begin{gathered}
m_{N O_{X}}=\left(\frac{\varepsilon_{\text {Coal }}}{1000} \cdot p_{\text {coal }}\right)+\left(\frac{\varepsilon_{B C}}{1000} \cdot p_{B C}\right)+\left(\frac{\varepsilon_{\text {gas }}}{1000} \cdot p_{\text {gas }}\right)= \\
\left(\frac{1724}{1000} \cdot \frac{14.2}{100}\right)+\left(\frac{1333}{1000} \cdot \frac{22.8}{100}\right)+\left(\frac{2841}{1000} \cdot \frac{13.17}{100}\right)=0.9228917 \mathrm{~g} / \mathrm{kWh}, \\
m_{C O}=\left(\frac{\varepsilon_{\text {Coal }}}{1000} \cdot p_{\text {coal }}\right)+\left(\frac{\varepsilon_{B C}}{1000} \cdot p_{B C}\right)+\left(\frac{\varepsilon_{\text {gas }}}{1000} \cdot p_{\text {gas }}\right)= \\
\left(\frac{62.64}{1000} \cdot \frac{14.2}{100}\right)+\left(\frac{164.8}{1000} \cdot \frac{22.8}{100}\right)+\left(\frac{956.2}{1000} \cdot \frac{13.17}{100}\right)=0.17240082 \mathrm{~g} / \mathrm{kWh}, \\
m_{P M}=\left(\frac{\varepsilon_{\text {Coal }}}{1000} \cdot p_{\text {coal }}\right)+\left(\frac{\varepsilon_{B C}}{1000} \cdot p_{B C}\right)+\left(\frac{\varepsilon_{\text {gas }}}{1000} \cdot p_{\text {gas }}\right)= \\
\left(\frac{54.89}{1000} \cdot \frac{14.2}{100}\right)+\left(\frac{74.58}{1000} \cdot \frac{22.8}{100}\right)+\left(\frac{0.043}{1000} \cdot \frac{13.17}{100}\right)=0.02480428 \mathrm{~g} / \mathrm{kWh},
\end{gathered}
$$

where $m_{N O_{X}}, m_{C O}, m_{P M}$ are the amounts of $\mathrm{NO}_{\mathrm{X}}, \mathrm{CO}$ and $\mathrm{PM}$ emissions from selected types of power plants $(\mathrm{g} / \mathrm{kWh}), \varepsilon_{n}$ is the emission factor of the power plant $(\mathrm{g} / \mathrm{MWh})$ and $p_{n}$ represents the percentage ratio of individual energy sources in the energy mix of Slovakia. 
Table 7. Specific production emissions corresponding to electricity consumption [23].

\begin{tabular}{|c|c|c|c|c|}
\hline & PM (g/MWh) & $\mathrm{SO}_{2}(\mathrm{~g} / \mathrm{MWh})$ & $\mathrm{NO}_{X}(\mathrm{~g} / \mathrm{MWh})$ & $\mathrm{CO}(\mathrm{g} / \mathrm{MWh})$ \\
\hline Black coal power plant & 54.89 & 1360 & 1724 & 62.64 \\
\hline Brown coal power plant & 74.58 & 1489 & 1333 & 164.8 \\
\hline Natural gas power plant & 0.043 & 0.234 & 2841 & 956.2 \\
\hline
\end{tabular}

These values relating to the $\mathrm{NO}_{\mathrm{X}}, \mathrm{CO}$ and $\mathrm{PM}$ emissions generated during the production of $1 \mathrm{kWh}$ will be converted into emissions generated during driving an $\mathrm{EV}$, per $1 \mathrm{~km}$ :

$$
\begin{aligned}
& m_{N O_{x} / 1 \mathrm{~km}}=P_{R E} \cdot \frac{m_{N O_{X}}}{100}=25.73 \cdot \frac{0.9228917}{100} \cong 0.23746 \mathrm{~g} / \mathrm{km}, \\
& m_{C O / 1 \mathrm{~km}}=P_{R E} \cdot \frac{m_{C O}}{100}=25.73 \cdot \frac{0.17240082}{100} \cong 0.04436 \mathrm{~g} / \mathrm{km}, \\
& m_{P M / 1 \mathrm{~km}}=P_{R E} \cdot \frac{m_{P M}}{100}=25.73 \cdot \frac{0.02480428}{100} \cong 0.00064 \mathrm{~g} / \mathrm{km},
\end{aligned}
$$

where $m_{N O_{X} / 1 \mathrm{~km}}, m_{\mathrm{CO} / 1 \mathrm{~km}}, m_{P M / 1 \mathrm{~km}}$ are the amounts of $\mathrm{CO}_{2}$ emissions per $1 \mathrm{~km}$ of ride $(\mathrm{g} / \mathrm{km})$ and $P_{R E}$ is the average consumption of electric vehicles based on Table $1(\mathrm{kWh} / 100 \mathrm{~km})$.

It is obvious from Table 8 that the emission values recalculated for the electric vehicle are not in all cases in favor of electromobility. For nitrogen emissions, the value per kilometer driven by an electric vehicle exceeds the prescribed European standard for diesel engines by almost three times, the standard for petrol engines by almost four times. The higher value of these emissions is caused mainly by the significant ratio of coal-fired power plants in our territory, which are among the major sources producing these pollutants. Emissions of carbon monoxide are forty times lower than allowed by the standard for petrol engines, and since transport, in particular, contributes to the production of this greenhouse gas, it can be said that electromobility would make a significant contribution to the improvement of this issue. In addition, particulate matter (PM) emissions are significantly lower for electric vehicles than for diesel engines. All values are compared to the EURO 6 standard, which represents the worst permissible pollution. It can be assumed that many vehicles exceed this standard many times over.

Table 8. Comparison of electric vehicle emissions with the EURO 6 standard.

\begin{tabular}{cccc}
\hline & $\mathrm{CO}(\mathrm{g} / \mathbf{k m})$ & $\mathrm{NO}_{\mathbf{X}}(\mathrm{g} / \mathbf{k m})$ & $\mathbf{P M}(\mathrm{g} / \mathbf{k m})$ \\
\hline Electric motor & 0.04436 & 0.23746 & 0.00064 \\
Diesel engine & 0.50 & 0.08 & 0.005 \\
Gasoline engine & 1.00 & 0.06 & 0.005 \\
\hline
\end{tabular}

In summary, electromobility can be a tool not only for new vehicles to comply with emission requirements and standards, but also to improve the environmental situation and reduce overall emissions and pollutants.

\section{Conclusions}

Currently, one of the most important and most represented areas of transport is transport by passenger vehicles. This fact brings with it many risks and problems, especially in terms of environmental pollution, as passenger cars are a huge producer of greenhouse gases and other harmful substances. Air pollution, especially in large cities, often exceeds the permitted limits, which has a very negative effect on human health. Not only this, but also other factors, such as the limited supply of fossil fuels, make it possible to look for various alternative propulsions in transport, including electric vehicles. Despite many skeptical attitudes, electromobility already has considerable European and public support, which includes subsidies from each European country. 
The aim of this study was to determine the possible impact of the expected future development of electromobility on the energy industry and the ecological situation. The analysis is based on our own calculations and in the end, the knowledge achieved is summarized and possible scenarios are deduced. It can be stated that despite the estimated increase in the number of EVs according to the forecasts of the Integrated National Energy and Climate Plan for the years 2021-2030, it is clear that there will be no significant changes in the electricity system. From an ecological point of view, with Slovakian current energy mix, electromobility does not yet appear to be the most effective tool for reducing emissions. Although the calculated amount of carbon dioxide emissions per driven kilometer is slightly lower than the average value of vehicles with internal combustion engines, it still exceeds the set limits of the European Union. CO and particulate emissions, on the other hand, are significantly lower for electric vehicles than allowed by the EURO 6 standard. Electromobility is most important if the energy situation develops in favor of low-emission energy sources such as renewables and nuclear. By reducing the number of coal-fired power plants, which are among the most important sources of air pollutants, electricity will be considered cleaner, and therefore transport by EVs will also significantly outperform vehicles with internal combustion engines.

Author Contributions: Conceptualization, J.Ž., J.K. and L.L.; methodology, J.Ž. and J.K.; investigation, M.P., M.K. and L.L.; data analysis, J.K. and L.L.; writing—original draft preparation, J.K., M.K. and L.L.; writing-review and editing, M.P. All authors have read and agreed to the published version of the manuscript.

Funding: This paper was developed within the project implementation: KEGA 009TUKE-4/2020 “Transfer of Digitization into Education in the Study Program Business Management and Economics." This work was supported by the Slovak Research and Development Agency under the Contract no. APVV-19-0328.

Conflicts of Interest: The authors declare no conflict of interest.

\section{References}

1. Lipka, M.; Rajewski, A. Regress in nuclear district heating. The need for rethinking cogeneration. Prog. Nucl. Energy 2020, 130, 9. [CrossRef]

2. Commission Staff Working Document. Country Report Slovakia 2019. Available online: https://ec.europa. eu/info/sites/info/files/file_import/2019-european-semester-country-report-slovakia_en.pdf (accessed on 17 November 2020).

3. Ministry of Economy of the Slovak Republic. Integrated National Energy and Climate Plan for 2021-2030. Available online: https://www.mhsr.sk/uploads/files/zsrwR58V.pdf (accessed on 17 November 2020).

4. Ministry of Economy of the Slovak Republic. Action Plan for the Development of Electromobility in the Slovak Republic. Available online: https:/www.mhsr.sk/uploads/files/5wuw3LIe.pdf (accessed on 17 November 2020).

5. Ministry of Economy of the Slovak Republic. Electromobility in the Slovak Republic in Numbers. Available online: https://e-mobility.sk/wp-content/uploads/2020/08/Elektromobilita-v-\%C4\%8D\%C3\%ADslach-Q22020.pdf (accessed on 18 November 2020).

6. Apostolaki-Iosifidou, E.; Codani, P.; Kempton, W. Measurement of power loss during electric vehicle charging and discharging. Energy 2017, 127, 730-742. [CrossRef]

7. ADAC. Ecotest 2019: Die Saubersten Autos. Available online: https://www.adac.de/rund-ums-fahrzeug/ tests/ecotest/ecotest-ranking-sauberste-autos/ (accessed on 20 November 2020).

8. Mihók, P. Understanding political institutional support for completing the Mochovce nuclear power plant. Prog. Nucl. Energy 2020, 120, 8. [CrossRef]

9. Čišková, L.; Drobný, M.; Hubinský, R.; Kabát, L.; Lacko, L'. Electromobiliy 2019. Annual Report, 2018, 100. Available online: https://www.pcrevue.sk/library/PDFARCHIV/Elektromobilita2018.pdf (accessed on 19 November 2020).

10. Regulatory Office for Network Industries. Annual Report 2019. Available online: http://www.urso.gov.sk/ ?language $=$ en (accessed on 21 November 2020).

11. Ministry of Economy of the Slovak Republic. Support of Clean Mobility in Slovakia. Available online: https://www. mzp.cz/C1257458002F0DC7/cz/cista_mobilita_seminar/\$FILE/OPZPUR-01_MZP_SR-20180413.pdf (accessed on 21 November 2020). 
12. National Issue System of Emissions of the Slovak Republic. National Inventory Report of the Slovak Republic. Available online: https://ghg-inventory.shmu.sk/documents.php?download=776 (accessed on 20 November 2020).

13. Repíková, M. Development of Electromobility and its Impact on Fuel and Electricity Consumption in Road Transport in the Slovak Republic. Analysis, December 2019. Available online: https://www.economy.gov.sk/ uploads/files/HK7WdBUi.pdf(accessed on 21 November 2020).

14. European Environment Agency. Europe's Policies and Sustainability Goals. The European Environment-State and Outlook; EEA: Copenhagen, Denmark, 2020; pp. 34-70. ISBN 978-92-9480-090-9. [CrossRef]

15. European Environment Agency. How Environmentally Friendly are Electric Vehicles? Electric Vehicles in Europe; EEA: Copenhagen, Denmark, 2016; Volume 20, pp. 41-45. ISSN 1977-8449. [CrossRef]

16. Wilson, L. Shades of Green: Electric Cars' Carbon Emissions around the Globe; The National Academies of Sciences, Engineering, and Medicine: Washington, DC, USA, 2013; pp. 11-15.

17. Elbakian, A.; Sentyakov, B.; Bozek, P.; Kuric, I.; Sentyakov, K. Automated separation of basalt fiber and other earth resources by the means of acoustic vibrations. Acta Montan. Slovaca 2018, 23, 271-281.

18. Groot, M.; Crijns-Graus, W.; Harmsen, R. The effects of variable renewable electricity on energy efficiency and full load hours of fossil-fired power plants in the European Union. Energy 2017, 138, 575-589. [CrossRef]

19. Honza, J.; Mareček, A. Chemie Pro Čtyřletá Gymnázia 1; Nakladatel'stvo Vyuka Nazorne: Olomouc, Czech Republik, 2013; ISBN 978-80-9024-020-9.

20. Semenova, A.; Tarasov, A.; Goodilin, E. Periodic table of elements and nanotechnology. Mendeleev Commun. 2019, 29, 479-485. [CrossRef]

21. Araújo, I.; Jackson, W.R.; Netto, A.; Perobelli, F. European Union membership and $\mathrm{CO}_{2}$ emissions: A structural decomposition analysis. Struct. Chang. Econ. Dyn. 2020, 55, 190-203. [CrossRef]

22. Kuric, I.; Cisar, M.; Tlach, V.; Zajacko, I.; Gál, T.; Więcek, D. Technical diagnostics at the department of automation and production systems. Adv. Intell. Syst. Comput. 2019, 835, 474-484.

23. Harris, S.; Weinzettel, J.; Bigano, A.; Källmén, A. Low carbon cities in 2050? GHG emissions of European cities using production-based and consumption-based emission accounting methods. J. Clean. Prod. 2020, 248, 119206. [CrossRef]

24. Cravero, C.; Marsano, D. Numerical Prediction of Tonal Noise in Centrifugal Blowers. In Proceedings of the ASME Turbo Expo 2018: Turbomachinery Technical Conference and Exposition, ASME Paper GT2018-75243, Oslo, Norway, 11-15 June 2018.

25. Velarde, S.; Tajadura, R. Numerical Simulation of the aerodynamic tonal noise generation in a backward-curved blades centrifugal fan. J. Sound Vib. 2006, 295, 781-786.

26. Kniewald, D.; Guzanová, A.; Brezinová, J. Utilization of Fractal analysis in strength prediction of adhesively-bonded joints. J. Adh. Sci. Tech. 2008, 22, 1-13. [CrossRef]

27. Puškár, M.; Bigoš, P. Output Performance Increase of Two-stroke Combustion Engine with Detonation Combustion Optimization. Stroj. Čas. Teor. Praksu Stroj. 2010, 52, 577-587.

28. Brestovič, T.; Jasminská, N.; Čarnogurská, M.; Puškár, M.; Kelemen, M.; Fil'o, M. Measuring of thermal characteristics for Peltier thermopile using calorimetric method. Measurement 2014, 53, 40-48. [CrossRef]

Publisher's Note: MDPI stays neutral with regard to jurisdictional claims in published maps and institutional affiliations.

(C) 2020 by the authors. Licensee MDPI, Basel, Switzerland. This article is an open access article distributed under the terms and conditions of the Creative Commons Attribution (CC BY) license (http://creativecommons.org/licenses/by/4.0/). 